\title{
BIOEDUSCIENCE
}

ISSN: 2614-1558

http://journal.uhamka.ac.id/index.php/bioeduscience

\section{Tetragonula laeviceps (Hymenoptera: Apidae: Meliponini): Morphology, Morphometric, and Nest Structure}

\author{
Manap Trianto $^{1 *}$, Fajri Marisa ${ }^{1}$, Moh Dahri Kisman ${ }^{1}$ \\ 1 Faculty of Biology, Universitas Gadjah Mada, Jl. Teknika Selatan, Sekip Utara, Bulaksumur, Sleman, Yogyakarta, Indonesia 55281 \\ *Corespondent email: manaptrianto@mail.ugm.ac.id
}

\section{ARTICLE INFO:}

Article history:

Received: 17 Apr 2020

Accepted: 02 Des 2020

Published: 31 Des 2020

Keywords:
Meliponini
Morphology
Morphometric
Nest structure
Tetragonula laeviceps

\section{Kata kunci:}

Meliponini

Morfologi

Morfometri

Struktur sarang

Tetragonula laeviceps

\section{A B S T R A C T}

Background: Stingless bees is one group of eusocial insects living together in the hive. There are around 46 species of stingless bee in Indonesia with different morphological, morphometric and hive structure characteristics. This study aimed to describe the morphological, morphometric and beehives structure of Tetragonula laeviceps from Yogyakarta. Methods: Survey method is used by taking three sampling points of bamboo, house building and livestock crates in Bantul Regency. Sampling points determined by Purposive sampling method. An XSZ-107 BN binocular microscope analyzed samples of $T$. laeviceps with Optilab viewer and Image Raster software. Results: The results showed morphological characters of T. laeviceps are dominated shiny-black body, brownish-yellow antennas, klipeus on a head covered by fine silver hair, brownish-yellow mandible with two teeth, mesonotum in thorax covered by brownish to black hair, scutellum extended to propodeum, the ribbon of hair on the dorsal thorax is not very clear, and the hind tibia is rather hairy. Morphometric of T. laeviceps included body length between $3.44-3.76 \mathrm{~mm}$, head width $1.55-1.70 \mathrm{~mm}$, front wing length with tegula $3.76-4.37 \mathrm{~mm}$, length of rear limbs tibia 1.37$1.57 \mathrm{~mm}$, and the number of hamuli as many as 5 . The beehive structure consisted of oval-shaped entrance formed funnel and varying internal hive in terms of the number of saplings, pollen cells, and honey cells. Conclusions: T. laeviceps have morphological, morphometric and hive structure characteristics that are different from other species and variated compared to similar species from other regions.

Tetragonula laeviceps (Hymenoptera: Apidae: Meliponini): morfologi, morfometri, dan struktur sarang

\section{A B S T R A K}

Background: Stingless bees merupakan salah satu kelompok serangga eusosial yang hidup bersama di dalam sarang. Di Indonesia terdapat sekitar 46 spesies lebah tanpa sengat dengan karakter morfologi, morfometri dan struktur sarang yang berbeda. Penelitian ini bertujuan untuk mendeskripsikan karakter morfologi, morfometri dan struktur sarang lebah tanpa sengat Tetragonula laeviceps dari Yogyakarta. Metode: Metode survey digunakan dalam penelitian ini dengan mengambil tiga titik sampling di Kabupaten Bantul yaitu bambu, bangunan rumah dan peti peternakan. Penentuan titik sampling menggunakan Purposive sampling method. Sampel lebah tanpa sengat T. laeviceps yang diambil dianalisis menggunakan Mikroskop binokuler XSZ-107 BN dengan Optilab viewer dan perangkat lunak Image Raster. Hasil: Hasil penelitian menunjukkan $T$. laeviceps memiliki karakter morfologi tubuh dominan berwarna hitam mengkilap, antena kuning kecoklatan, klipeus pada kepala ditutupi rambut halus berwarna perak, mandibula kuning kecoklatan dengan dua gigi, mesonotum pada thoraks ditutupi rambut berwarna kecoklatan hingga hitam, skutelum memanjang hingga ke bagian propodeum, pita rambut pada dorsal thoraks tidak terlalu jelas, dan tibia belakang agak berambut. Morfometrik lebah tanpa sengat T. laeviceps di antaranya panjang tubuh antara 3,44-3,76 mm, lebar kepala 1,55-1,70 mm, panjang sayap depan dengan tegula 3,76-4,37 mm, panjang tibia tungkai belakang 1,37-1,57 $\mathrm{mm}$, dan jumlah hamuli sebanyak 5. Struktur sarang terdiri atas pintu masuk berbentuk oval membentuk corong, dengan internal sarang yang bervariasi dalah hal jumlah sel-sel anakan, sel-sel polen, dan sel-sel madu. Kesimpulan: Lebah tanpa sengat $T$. laeviceps memiliki karakter morfologi, morfometri dan 
struktur sarang yang berbeda dengan spesies lainnya dan memiliki variasi jika dibandingkan dengan spesies serupa dari daerah lainnya.

(C) 2020 by authors. Lisensi Bioeduscience, UHAMKA, Jakarta. This article is open access distributed under the terms and conditions of Creative Commons Attribution (CC-BY) license.

\section{Introduction}

Stingless bees are a eusocial insect that lives together in a colony and has many important life roles. These bees are classified in Apidae, subfamily Apinae, and tribe Meliponini (Borror, D. Triplehorn, C., \& Johnson 1992; Michener 1944; Trianto, M., Kaini, Saliyem, Warsih, E. 2020). Stingless bees include bees with a large number of genera, which is about 55 genera divided into 61 sub-genera with different morphological, morphometric, and nest structure characters for each species (Rasmussen 2008; Trianto, M., Kaini, Saliyem, Warsih, E. 2020). One species of stingless bees is Tetragonula laeviceps, spread across in island, one of them in Java to be precise in Bantul Regency, Special Region of Yogyakarta Province.

Tetragonula laeviceps is one species of stingless bees. The morphological characteristics of T. laeviceps is the body predominantly shiny black, mesoscutum black and fully covered with yellowish setae in posterior. The number of hamuli 5 per hindwing (Cockerell 1911; Smith 2012; Trianto, M., \& Purwanto 2020). In nature, this bee has a morphometric size that varies from region to region. These bees can also be found in almost all habitats or locations ranging from dead tree trunks, bamboo, and house buildings with a distance of about 1-5 m from the ground. The nest structure consists of the nest entrance in a tube surrounded by a blackish resin. The hive is mouth can be in the form of internal and external tubes as a way for bees to enter and exit the hive internall (Chinh et al., 2005).

In the identification process of stingless bees, based on morphological characteristics, morphometric, and nest structure need to be known because they can help determine the type of stingless bees themselves. This information can be also used as initial information before carrying out the cultivation or conservation process of stingless bees.

Research on the morphological characteristics, morphometric, and nest structure of T. laeviceps it's very lacking. Currently, research on these species is still limited to diversity (Suriawanto, Atmowidi, and Kahono 2017; Trianto, M., Kaini, Saliyem, Warsih, E. 2020), description of the entrance to the nest and source of food (Rizka, 2016). This study described morphological characteristics, morphometric, and nest structure of T. laeviceps from Bantul Regency, Special Region of Yogyakarta Province.

\section{Methods}

This research was carried out from June 2019 in Bantul Regency, Special Region of Yogyakarta from several places (bamboo, house buildings, and beekeeping) (Figure 1).

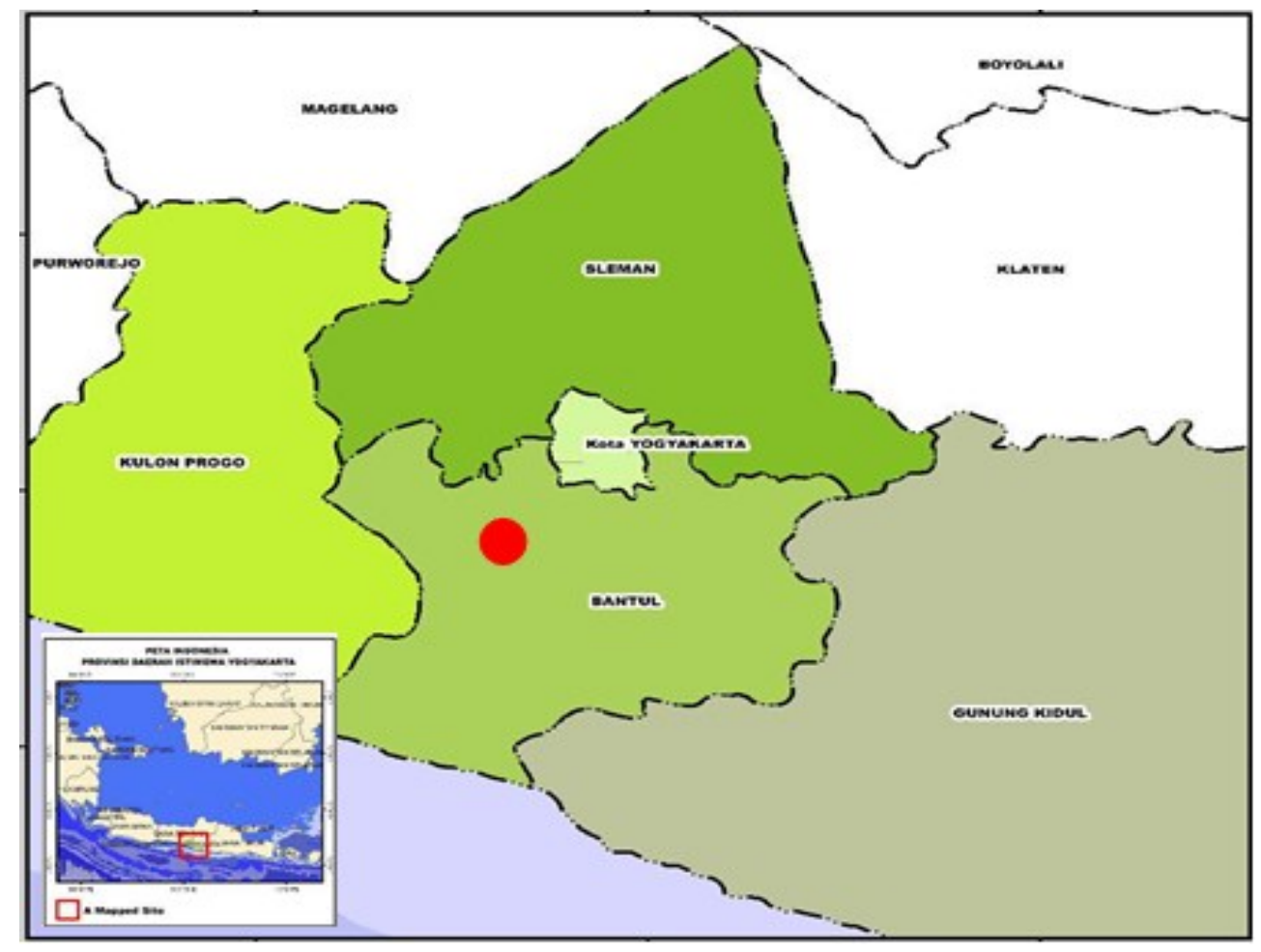

Figure 1. Study site employed for the sampling of T. laeviceps in Bantul Regency, Special Region of Yogyakarta, Indonesia 
The stingless bee specimen were identified in Entomology Laboratory, Faculty of Biology, Universitas Gadjah Mada. Stingless bee specimen identified based on morphology, morphometrics, and nest structure as described by (Sakagami 1978; Smith 2012; Suriawanto, Atmowidi, and Kahono 2017; Trianto, M., \& Purwanto 2020).

The tools and materials in this research are memmert oven UN 55 53L, OptiLab Professional, XSZ-107 BN binocular microscope, camera Canon EOS 1100D, T. laeviceps colony, ethyl acetate, Chirurgie tweezers $12 \mathrm{~cm}$, pinning needle 0,1 mm, Schott Duran petri dish $10 \mathrm{~cm}$, cotton, clear plastic $10 \times 20 \mathrm{~cm}$, styrofoam $60 \mathrm{~cm}$ x $60 \mathrm{~cm}$., brush $3 / 0$, label paper, and a razor blade.

Determination of sampling sites using a roaming method. Total of 3 colonies of T. laeviceps was used as a sample. The specimens collected (15 individuals of each colony) were put into a bottle with $96 \%$ ethanol. Next, perform the pining process by an insect needle into the mesoscutum. Samples are dried in the oven at 35 degree Celsius for $24 \mathrm{hrs}$.

Observations of the entrance and internal structure of the nest were carried out at three stingless bee colonies. The entrance to the nest was observed for the shape, colour and surface texture. The internal structures of the hives that were observed were tiller cells, pollen cells, and honey cells (Suriawanto et al., 2017) (Figure 2).

\section{Data analysis}

Data analysis was performed by calculating the minimum and maximum length $(\mathrm{mm})$ of the measurement of the morphometric characters of the stingless bee, namely body length (BL), head width (HW), length of forewing including tegula (WL1), the distance between M$\mathrm{Cu}$ bifurcation (WL2), and hind tibia length (HTL). Calculate the percentage area of the stingless bee nest composition, namely nest area / total nest area x 100\%.

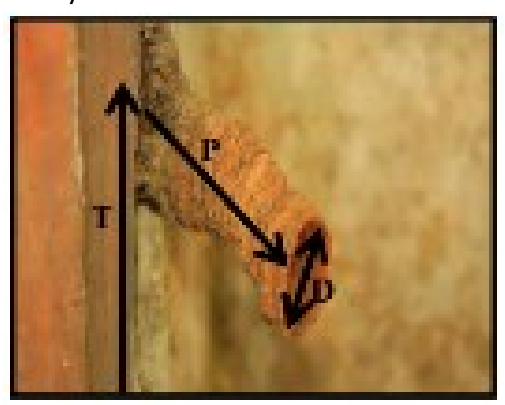

Figure 2. Stingless bee honeycomb entrance: height from ground level (T), length of the entrance (P), and diameter of nest entrance (D).

\section{Results}

\section{Morphological characteristics of T. laeviceps}

The body of $T$. laeviceps predominantly shiny black. Compound eyes reddish, ocelli blackish and large. Clypeus blackhead and fully covered with fine white hairs. Antennal has 11 flagellomeres, scape yellowish-brown, and pedicel brown. Mandible has two teeth and the colour brown and slightly black in basal. Mesoscutum black and fully covered with yellowish setae in posterior. Tegula is brown. Hind tibiae short, corbicula pear shape, sparsely covered with long setae in apical but short in basal, entirely black and basitarsi is wholly black. First to five gastral tergites are fully dark brown in dorsal-the number of hamuli 5 per hindwing (Figure 3).

\section{Morphometric characteristics of T. laeviceps}

Colony 1 originates from the bamboo cavity. Colony 1 worker bees have the following characteristics: body length is $3.15-4.21 \mathrm{~mm}$, length of forewing including tegula (WL1) is $3.79-4.65 \mathrm{~mm}$, the distance between $\mathrm{M}-\mathrm{Cu}$ bifurcation (WL2) is $1.08-1.20 \mathrm{~mm}$, malar length (ML) is $0.02-0.04 \mathrm{~mm}$, hind tibia width (HTW) is $0.32-0.49 \mathrm{~mm}$, and hind basitarsus width (HBW) is $0.15-0.23 \mathrm{~mm}$ with the ratio average $\mathrm{HBW} / \mathrm{HTW}$ is $0.48 \mathrm{~mm}$.

Colony 2 derive from the building cavity. The colony 2 worker bees have the following characteristics: body length is 3.50-4.09 $\mathrm{mm}$, length of forewing including tegula (WL1) is $3.90-4.62 \mathrm{~mm}$, the distance between $\mathrm{M}-\mathrm{Cu}$ bifurcation (WL2) is $1.05-1.17 \mathrm{~mm}$, malar length (ML) is $0.03-0.04 \mathrm{~mm}$, hind tibia width (HTW) is $0.32-0.43 \mathrm{~mm}$, and hind basitarsus width (HBW) is $0.25-0.36 \mathrm{~mm}$ with the ratio average $\mathrm{HBW} / \mathrm{HTW}$ is $0.49 \mathrm{~mm}$.

Colony 3 worker bees have the following characteristics: body length is 3.05-4.06 mm, length of forewing including tegula (WL1) is $3.49-4.87 \mathrm{~mm}$, the distance between M-Cu bifurcation (WL2) is $0.88-1.09 \mathrm{~mm}$, malar length (ML) is $0.03-0.04 \mathrm{~mm}$, hind tibia width (HTW) is $0.38-0.42 \mathrm{~mm}$, and hind basitarsus width (HBW) is 0.23 $0.30 \mathrm{~mm}$ with the ratio average $\mathrm{HBW} / \mathrm{HTW}$ is $0.48 \mathrm{~mm}$. They are derived from the beekeeping.

The colonies of $T$. laeviceps $(1,2$, and 3 ) were at a great distance from those reported by Sakagami (1978), in particular on the character of body length (BL), head width (HW), length of forewing including tegula (WL1), the distance between $\mathrm{M}-\mathrm{Cu}$ bifurcation (WL2), and hind tibia length (HTL) (Table 1) (Figure 4). 


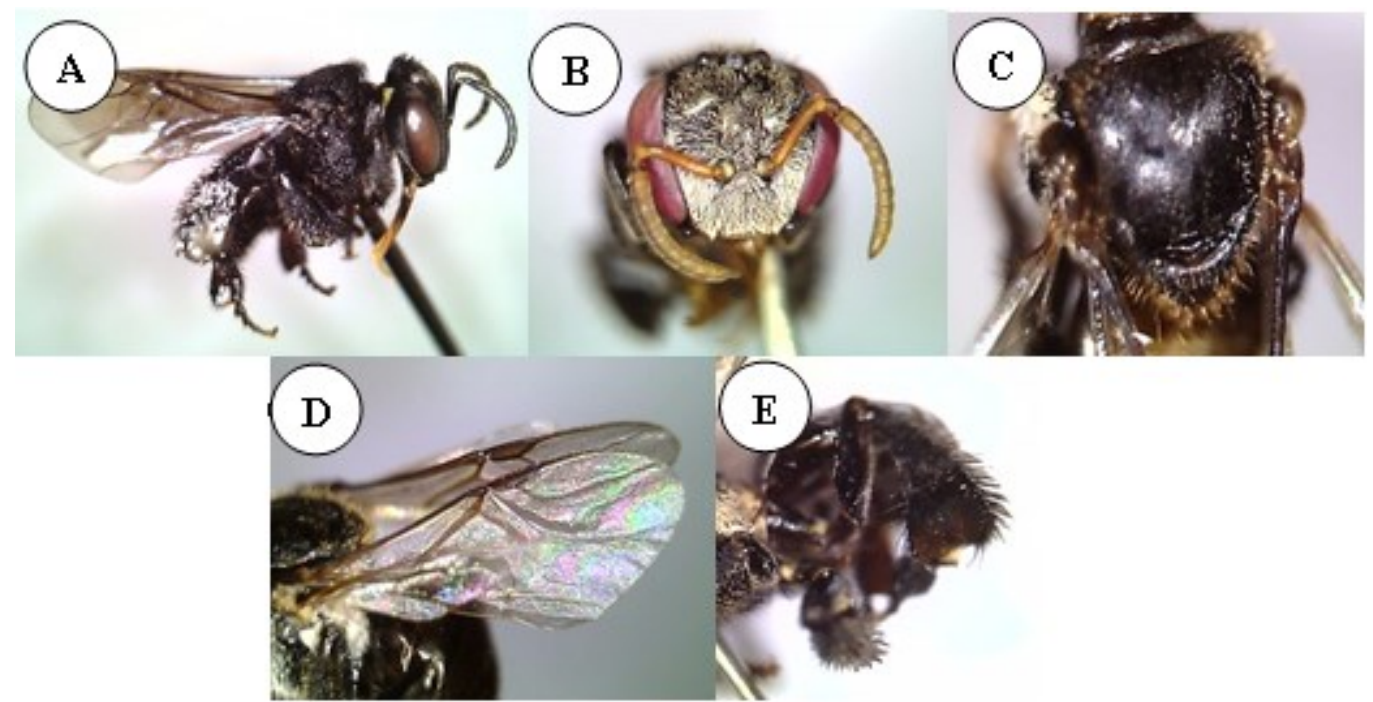

Figure 3. Morphological characteristics of T. laeviceps. (A) habitus (lateral view); (B) frons; (C) mesoscutum; (D) forewing; (E) hind tibia.

Table 1. Comparison of the five characters of the three colonies T. laeviceps with Sakagami (1978)

\begin{tabular}{lcccc}
\hline Characters & Colony 1 & Colony 2 & Colony 3 & Sakagami (1978) \\
\hline BL & 3.76 & 3.76 & 3.44 & $3.4-4.9$ \\
HW & 1.68 & 1.70 & 1.55 & $1.8-2.0$ \\
WL1 & 4.37 & 4.32 & 3.76 & $3.7-5.0$ \\
WL2 & 1.14 & 1.12 & 1.04 & $1.2-1.4$ \\
HTL & 1.55 & 1.57 & 1.37 & $1.7-1.9$ \\
\hline
\end{tabular}

Note: $B L=$ body length; $H W=$ head width; $W L 1$ = length of forewing including tegula; $W L 2$ = distance between M-Cu bifurcation; $H T L=$ hind tibia length (unit of measure: $\mathrm{mm}$ ).

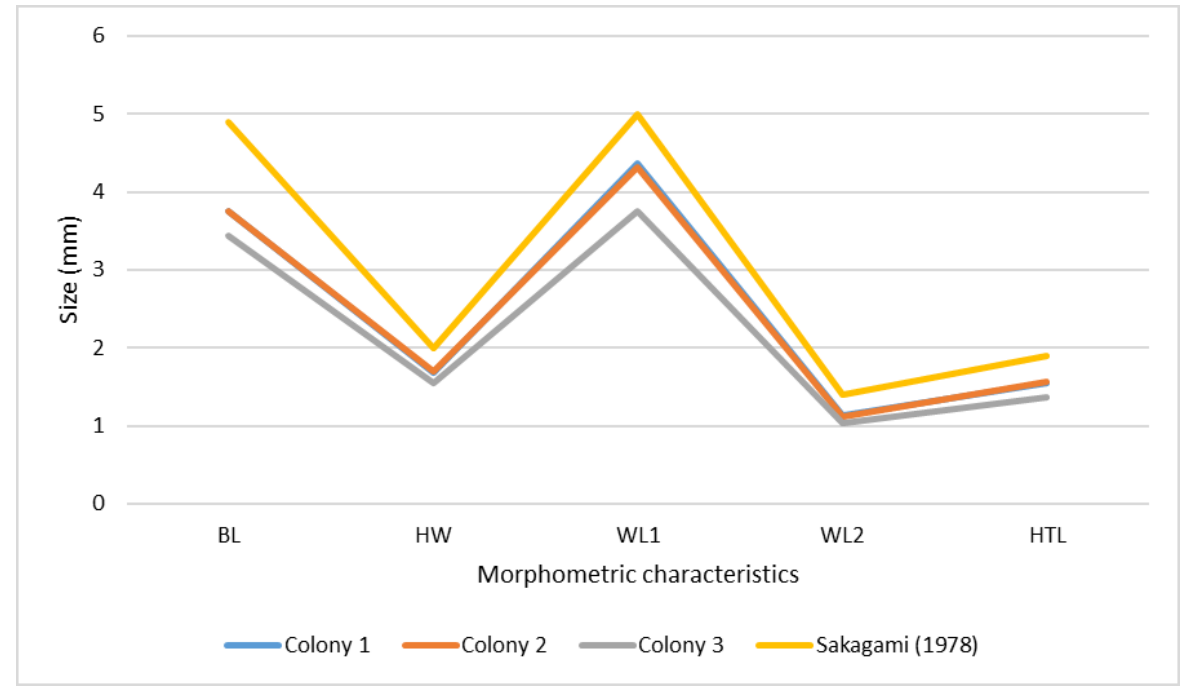

Figure 4. Comparison of morphometric characteristics of T. laeviceps

\section{Nest structure of T. laeviceps}

Three colonies of T. laeviceps were observed in bamboo cavities (Figure 5), building cavities (Figure 6) and beekeeping (Figure 7). Overall, the entrance to the nests in colonies 1, 2 and 3 is in the form of oval holes, with shortlong tubes, yellow to brownish-black, and the texture of the entrance to the nest is soft or not hard (Figure 5-7).
In the colony, honey cells can be distinguished from pollen cells and brood cells. Honey cells are blackishbrown, and pollen cells are brown. Brood cells are smaller than honey cells and light brown. Also, in the nest, there aral visible rocks surrounding (Figure 8). The composition nest of $T$. laeviceps is brood cells (51.44\%), honey cells (20.49\%), pollen cells (16.28\%), and batumen $(11.79 \%)$ (Table 2). 

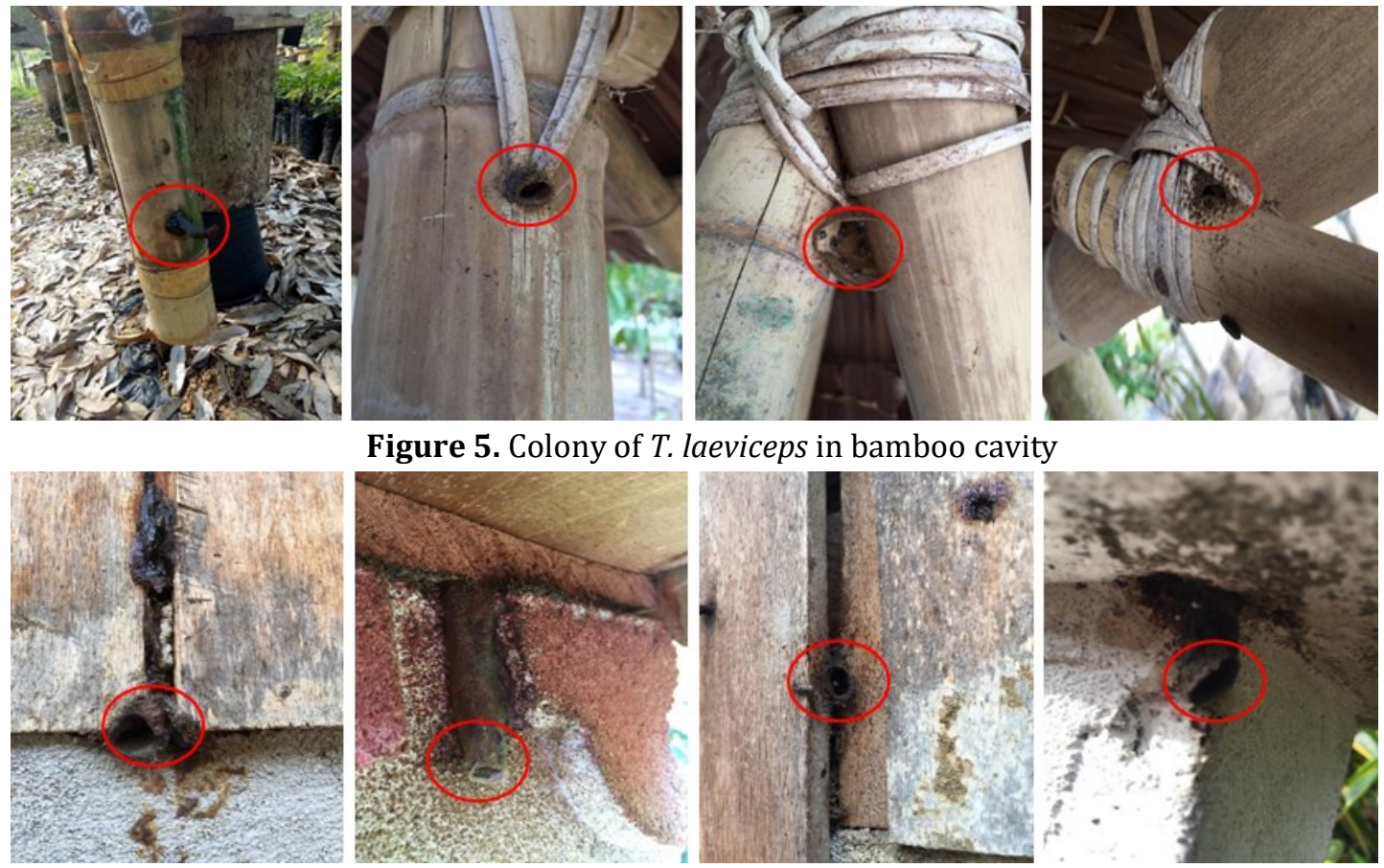

Figure 5. Colony of T. laeviceps in bamboo cavity

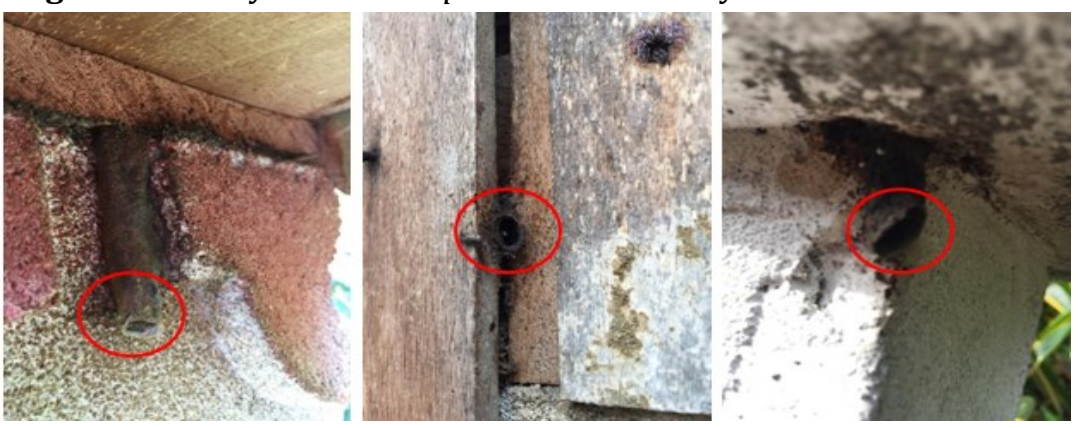

Figure 6. Colony of T. laeviceps in building cavity
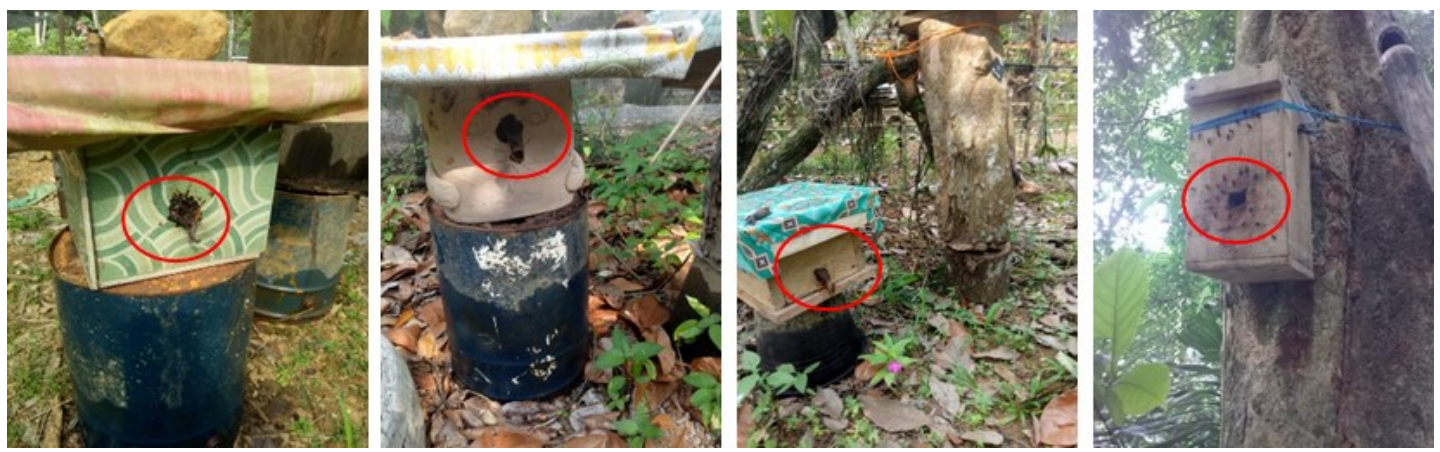

Figure 7. The colony of T. laeviceps in beekeeping

Table 2. Composition nest of T. laeviceps

\begin{tabular}{lcc}
\hline \multicolumn{1}{c}{ Cells } & Large $(\mathrm{cm})$ & Percentage $(\%)$ \\
\hline Brood cells & 45,82 & 51,44 \\
Pollen cells & 14,50 & 16,28 \\
Honey cells & 18,25 & 20,49 \\
Batumen & 10.50 & 11,79 \\
Total & 89,07 & 100 \\
\hline
\end{tabular}

\section{DISCUSSIONS}

\section{Morphological and morphometric characteristics of $T$. laeviceps}

The morphological characters of the T. laeviceps from this study are the body predominantly shiny black. Compound eyes reddish, ocelli blackish and large. Clypeus blackhead and fully covered with fine white hairs. Antennal has 11 flagellomeres, scape yellowish-brown, and pedicel brown. Mandible has two teeth and the colour brown and slightly black in basal. Mesoscutum black and fully covered with yellowish setae in posterior. Tegula is brown. Hind tibiae short, corbicula pear shape, sparsely covered with long setae in apical but short in basal, entirely black and basitarsi is wholly black. First to five gastral tergites are fully dark brown in dorsal. The number of hamuli 5 per hindwing. The morphological characters following the description of Efin, A., Atmowidi, T., \& Prawasti (2019), Karimah (2017). Manarudin (2019), Sakagami, S. F., Inoue, T., \& Salmah (1990), Sakagami (1978), Smith (2012), Trianto and Purwanto (2020).

Furthermore, T. laeviceps specimen in this study have a body size (3.44-3.76 $\mathrm{mm})$, shorter than the specimen described by Sakagami (1978) that was using a specimen from Sri Lanka and Asia (4.00-4.60 mm) and specimen from Banten (4.31-4.58 mm) (Efin et al. 2019). Meanwhile, when compared with the specimen by Michener, (1944) and Smith, (2012), who used specimen from Singapore $(3.50 \mathrm{~mm})$ and who used specimen from Sulawesi (3.40$3.43 \mathrm{~mm}$ ) (Suriawanto et al. 2017), who used samples from Special Region of Yogyakarta (3.64-3.68 mm), the specimen 
in this study had a longer body size (Trianto and Purwanto, 2020).

The workers' bees of T. laeviceps of this study have different sizes, but not too significant. In contrast, the specimen's morphometry has variation in size compared to the same species reported from other areas. The differences in the size of the worker bees are a morphological adaptation to different environmental conditions. Gaston, (2008) and Novita et al. (2013) concluded that changes in temperature or environmental conditions would cause living things to adapt morphologically to adjust to the environment flight and foraging activities. Also, this variation is supported by Roubik, (2006) and Ruttner, (1987) that the body size of worker bees is generally considered form of adaptation in foraging activities and exploiting flower resources. Furthermore, the result of this study similar to research by Novita et al. (2013) and Raffiudin et al. (1999) using the honey bee samples (Apis cerana).

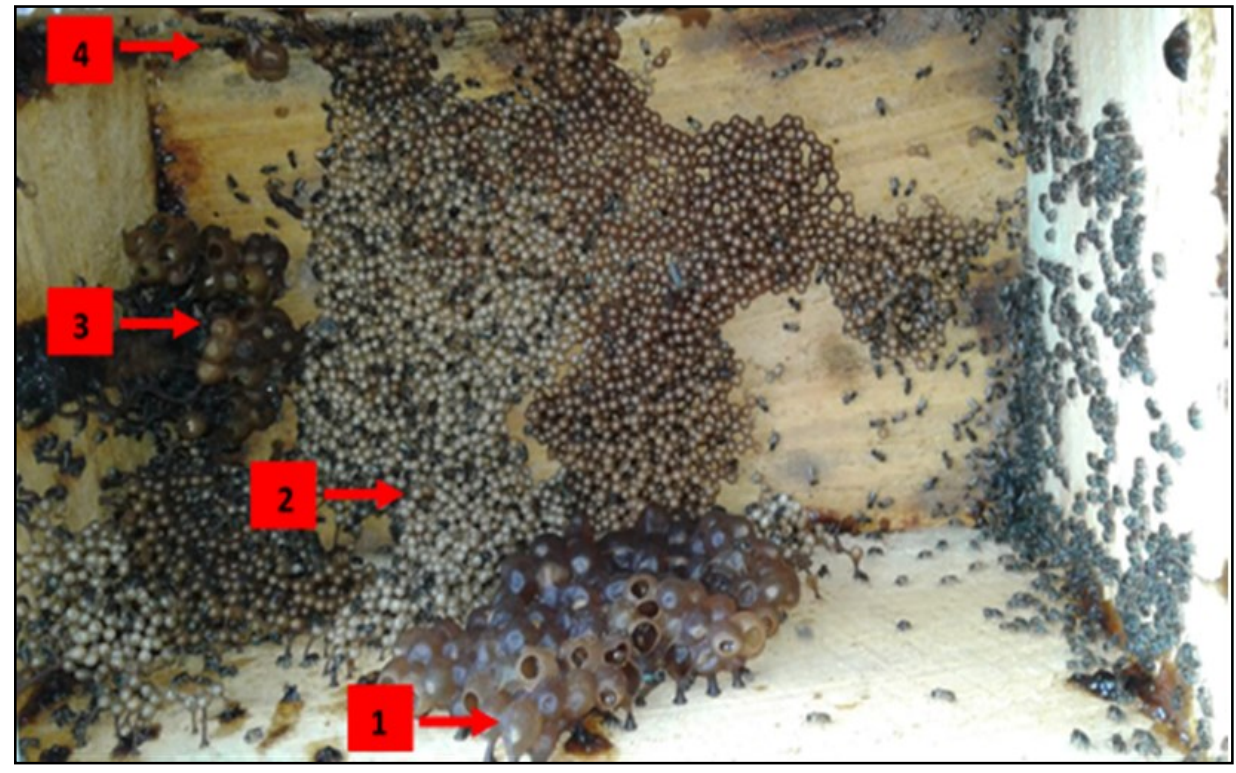

Figure 8. Internal nest structure of T. laeviceps. (1) honey cells; (2) brood cells; (3) pollen cells; (4) batumen

\section{Nest structure of T. laeviceps}

The nest structure of the T. laeviceps from this study consists of the nest entrance, honey cells, brood cells, pollen cells, and batumen. The nest structure described in this study, similar to the description of Karimah, (2017). Batumen is made from a mixture of wax and resin called cerumen (Michener, 1944). Batumen is a layer of cerumen that covers the entire surface of the nest. However, some stingless bees use mud as a mixture to form stone (Michener, 1944; Salmah et al., 1990).

Furthermore, Kelly et al. (2014) reported that the entrance to the T. laeviceps in Kelantan, Malaysia namely funnel-shaped, black, and rigid with a smooth and rough surface. Meanwhile, the entrance to the hives of stingless bees colonies 1 to 3 in this study is similar to data by Chinh et al. (2005). Also, Sakagami, (1978) reported that there were variations at the entrance to T. laeviceps nests, namely entrances with extended channels, nests without channels at the entrance but with rain protection (raintight) around them, and nests without channels and protection. According to Sakagami, (1978), there are variations in the stingless bees' entrance due to the hive's environmental conditions. Continuous nest entrances will be built in line with the growth of the stingless bee colony. The construction of the entrance to the nest decreases as the population in the colony decreases. Over time, a decrease in population causes a decrease in foraging activity and a narrowing of the nest entrance. Roubik, (2006) adds that the inlet's extension in the hive is caused by the age of the hive, genetic factors of bees and environmental conditions such as predators, parasites, symbionts, rain, wind and sun.

\section{Conclusions}

Based on the morphological characters and morphometric measurements, the stingless bee was identified as Tetragonula laeviceps. The composition nest of T. laeviceps is brood cells (51.44\%), honey cells $(20.49 \%)$, pollen cells (16.28\%), and batumen (11.79\%)

\section{Declaration statement}

The authors reported no potential conflict of interest.

\section{References}

Borror, D. Triplehorn, C., \& Johnson, N. 1992. Pengenalan Pelajaran Serangga. Yogyakarta: Gadjah Mada University Press.

Chinh, T. X., Sommeijer, M. J., Boot, W. J., \& Michener, C. D. 2005. "Nest and Colony Characteristics of Three Stingless Bee Species in Vietnam with the First 
Description of the Nest of Lisotrigona Carpenteri (Hymenoptera: Apidae: Meliponini)." Journal of The Kansas Entomological Society 78(4): 363-72.

Cockerell, T. D. A. (1911). 1911. "Descriptions and Records of Bees - LXXX." Annals and Magazine of Natural History 12(2): 384-90.

Efin, A., Atmowidi, T., \& Prawasti, T. S. 2019. "Morphological Characteristics and Morphometric of Stingless Bee (Apidae: Hymenoptera) from Banten Province, Indonesia." Biodiversitas 5(20): 1693-98.

Gaston, K. J., Chown, S. L., \& Evans, K. L. 2008. "Ecogeographical Rules: Elements of a Synthesis." Journal of Biogeography 3(35: 483-500.

Karimah, K. N. 2017. Morfologi Dan Struktur Sarang Tetragonula Laeviceps (Apidae: Meliponinae) Asal Subang Dan Sukabumi, Jawa Barat. Bogor: Pascasarjana Institut Pertanian Bogor.

Kelly, N., Farisya, M. S. N., Kumara, T. K., \& Marcela, P. 2014. "Species Diversity and External Nest Characteristics of Stingless Bees in Meliponiculture." Journal Tropical Agricultural Science 37(3): 293-98.

Manarudin, M. F. 2019. Morfologi Dan Morfometri Lebah Tanpa Sengat (Apidae: Meliponinae) Asal Pandeglang, Banten. Bogor: Pascasarjana Institut Pertanian Bogor.

Michener, C. D. 1944. "Comparative External Morphology, Phylogeny, and a Classification of the Bees." Bulletin of the American Museum of Natural History 20(82): 151326.

Novita, S., Rustama, \& Sutriyono. 2013. “Analisis Morfometrik Lebah Madu Pekerja Apis Cerana Budidaya Pada Dua Ketinggian Tempat Yang Berbeda." Jurnal Sains Perternakan Indonesia 8(1): 41-56.

Raffiudin, R., Sosromarsono, S., Ratna, E. S., \& Solihin, D. D. 1999. "Keragaman Morfologi Lebah Apis Cerana (Hymenoptera: Apidae) Di Jawa Barat." Buletin HPT 11(1): 20-25.

Rasmussen, C. 2008. "Catalog of the Indo-Malayan Australasian Stingless Bee (Hymenoptera: Apidae: Meliponini)." Zootaxa 15(3): 1-80.

Rizka. 2016. Deskripsi Pintu Masuk Sarang Lebah Tak Bersengat Di Provinsi Sulawesi Tengah. Palu: Pendidikan Biologi Universitas Tadulako.

Roubik, D. W. 2006. "Stingless Bee Nesting Biology." Journal Apidologie 37(2): 124-43.

Ruttner, F. 1987. Biogeography and Taxonomy of Honey Bees. Springer-Verlag Berlin Heidelberg GmbH.

Sakagami, S. F., Inoue, T., \& Salmah, S. 1990. Stingless Bees of Central Sumatra. Sapporo: Hokkaido Univ.

Sakagami, S. F. 1978. "Tetragonula Stingless Bees of the Continental Asia and Sri Lanka (Hymenoptera, Apidae)." Zoology 21(2): 165-247.
Salmah, S., Inoue, T., \& Sakagami, S. F. 1990. An Analysis of Apid Bee Richness (Apidae) in Central Sumatra. Sapporo: Hokkaido Univ.

Smith, D. R. (2012). 2012. "Key to Workers of Indo-Malayan Stingless Bees." For use in the Stingless Bees Workshop 1(1): 1-42.

Suriawanto, Nelky, Tri Atmowidi, and Sih Kahono. 2017. "Nesting Sites Characteristics of Stingless Bees (Hymenoptera: Apidae) in Central Sulawesi, Indonesia." Journal of Insect Biodiversity.

Trianto, M., \& Purwanto, H. 2020. "Molecular Phylogeny of Stingless Bees in the Special Region of Yogyakarta Revealed Using Partial 16S RRNA Mitochondrial Gene." Buletin Peternakan 44(4): 186-93.

Trianto, M., Kaini, Saliyem, Warsih, E., \& Winarsih. 2020. "Keanekaragaman Serangga Polinator Pada Tanaman Nanas (Ananas Comosus (L.) Merr.) Di Desa Bincau." Jurnal Penelitian Science dan Pendidikan 9(2): 154-62.

Trianto, Manap, and Hari Purwanto. 2020. "Morphological Characteristics and Morphometrics of Stingless Bees (Hymenoptera: Meliponini) in Yogyakarta, Indonesia." Biodiversitas. 